\author{
SEAWOMIR BARTNICKI \\ INSTYTUT SOCJOLOGII \\ UNIWERSYTETU W BIAŁYMSTOKU \\ E-MAIL: SLAWOMIR@UWB.EDU.PL
}

\title{
KONSULTACJE SPOŁECZNE JAKO ASPEKT DEMOKRACJI SEMIBEZPOŚREDNIEJ WE WŁADZTWIE GMINNYM WOJEWÓDZTWA PODLASKIEGO
}

Artykuł przedstawia analizę treści uchwał rad gminnych województwa podlaskiego odnoszących się do konsultacji społecznych na przestrzeni ostatnich pięciu lat. Wprowadzenie stanowi charakterystyka zjawisk takich, jak: konsultacje społeczne, demokracja bezpośrednia czy demokracja semibezpośrednia w kontekście władztwa samorządowego i państwowego.

W perspektywie postpolityki realnego znaczenia nabiera partycypacja obywateli w decydowaniu politycznym oraz w życiu publicznym w ogóle. Jakkolwiek nierealnie to dźwięczy w obecnym kontekście życia politycznego w Polsce oraz w innych krajach (w tym tzw. starych demokracji), zasada partycypacji, czyli czynne współdecydowanie przez obywateli w różnych formach, nieograniczające się tylko do aktywności w wyborach, wykazuje coraz większą presję odgórną i oddolną. Ta pierwsza jest widoczna w utrwalonych historycznie praktykach delegacji uprawnień i decentralizacji w państwach Europy Zachodniej i urzeczywistnia się choćby w stanowisku Komisji Europejskiej (KE), które mniej lub bardziej akceptują władze centralne państw członkowskich. W Polsce na fali tej presji sprokurowany został dokument Program „Lepsze regulacje 2015" , zakładający podniesienie roli konsultacji społecznych w stanowieniu prawa krajowego. Choć presję na jego powstanie wywarły i nadal wywierają wydarzenia takie jak protesty ws ACTA czy coraz częstsze domaganie się przez obywateli wpływu na kształt decyzji politycznych. Z tym faktem wiąże się presja oddolna, które jest wzmacniana m.in. przewartościowaniem efektywności demokracji pośredniej i problemami gospodarczymi demokracji liberalnych. Presja oddolna powstaje także, a może przede wszystkim na bazie 
rozwoju nowych mediów ułatwiających samoorganizację, komunikację i oferujących nowe zastosowania motywacjom delegitymizacyjnym obywateli.

Pojęcie demokracji bezpośredniej jest o tyle proste do zdefiniowania, co trudne do urzeczywistnienia w praktyce wskutek wielkości zbiorowości, stopnia trudności problemów do rozstrzygania oraz kultury danej zbiorowości, która może mniej lub bardziej predestynować ów podmiot, ale i władze do aktywowania demokracji bezpośredniej. Najogólniej, według jednego z nurtów definicyjnych, demokracja bezpośrednia nie występuje $\mathrm{w}$ praktyce decydowania politycznego, nie ma bowiem spełnionych warunków podstawowych jedności miejsca i czasu decyzji politycznych. Jedność miejsca i czasu zakłada, że uprawnieni do decydowania uczestniczą w całym procesie, od propozycji decyzji do jej prawnego przyjęcia [Uziębło 2009:13-14]. Powyższe warunki są wrażliwe na efekt skali, choć ta forma decydowania może występować np. w sytuacji zebrania sołeckiego. Drugi nurt definiowania zakłada, że demokracja bezpośrednia urzeczywistnia się wszędzie tam, gdzie obywatele mają możliwość wpływu na decyzje na dowolnym etapie ich powstawania. Trzeci sposób definiowania podkreśla, że demokracja bezpośrednia urzeczywistni się wówczas, kiedy suweren będzie w stanie podjąć ostateczną wiążącą decyzję [Uziębło 2009: 15-16]. Wedle tego, obecnie funkcjonujące w Polsce instytucje demokracji bezpośredniej są nimi jedynie według definicji drugiego nurtu. Według pierwszego i trzeciego sposobu definiowania, byłyby to jedynie instytucje fasadowe. Choć równocześnie, dyskusyjnym jest, czy rzeczywiście i w jakim stopniu, instytucje demokracji bezpośredniej w Polsce pozwalają na zadośćuczynienie wymogom drugiego nurtu definicji [Kossowska-Gąstoł 2004: 515-516].

Ideały demokracji bezpośredniej podkreśla klasyczne rozumienie demokracji, zwane też partycypacyjną teorią demokracji. Demokracja urzeczywistnia się tu dopiero w bezpośrednim udziale suwerena w kreowaniu i ustanawianiu decyzji bez pośrednictwa przedstawicieli. Nawiązuje to do ateńskiej i greckiej wizji demokracji - kształtowania decyzji przez obywateli. Natomiast współczesny kontekst funkcjonowania demokracji przedstawicielskich uzasadnia elitarystyczna teoria demokracji. W tym przypadku partycypacja obywatelska ma się ograniczać do cyklicznego uczestnictwa w wyborach; zasadą konstytutywną funkcjonowania reżimu demokratycznego jest demokracja pośrednia - przedstawicielska. W konkurencji elit politycznych o głosy suwerena manifestuje się ideał demokracji. Teoria elitarystyczna jest uzasadniona wielkością struktury demosu oraz stopniem skomplikowania rozstrzyganych spraw. Zasadną formą uczestnictwa obywatelskiego jest przekazanie władzy przez suwerena obieralnym przedstawicielom i nieangażowanie się w proces stanowienia decyzji politycznych. W takim ujmowaniu demokracji delegitymizacja rozumiana jako 
brak uczestnictwa w głosowaniu podlega racjonalizacji wskutek uzasadnienia, że niska frekwencja oznaczać może zadowolenie obywateli z funkcjonującego porządku [Cześnik 2007:13-20]. Aprobowany stopień zaangażowania obywateli w życie polityczne w teorii partycypacyjnej uosabia legitymizację substancjonalną [Wesołowski 2001], z kolei teoria elitarystyczna odwołuje się do legitymizacji proceduralnej. Obydwa podtypy legitymizacji wynikają z legitymizacji demokratycznej, z tym, że wskazują na różny stopień zaangażowania obywateli w praktyki polityczne, co sugeruje różne znaczenie jakościowe tych podtypów legitymizacji. Jeżeli kogoś wyróżnia legitymizacja substancjalna, to jednocześnie ten ktoś charakteryzuje się legitymizacją proceduralną. Z kolei legitymizowanie na poziomie proceduralnym nie oznacza jednocześnie obecności legitymizacji substancjalnej. Ta ostatnia wiąże się bowiem z bezpośrednim i aktywnym zaangażowaniem suwerena w aktywności polityczne wykraczające daleko poza uczestnictwo w różnych typach wyborów. Na przykład: uczestnictwo w konsultacjach społecznych, podpisywanie petycji i ich prokurowanie, udział w wiecach politycznych, przynależność do partii politycznej, bezpośrednie kontaktowanie się z decydentami, a w omawianym kontekście, również samodzielne kandydowanie w wyborach samorządowych czy udział w posiedzeniach rad gminnych. Legitymizacja substancjalna rozumiana przez klasyczne rozumienie demokracji wyrażone przez teorię partycypacyjną wymaga względnie wysokich kompetencji politycznych, bo zakłada zaangażowanie obywateli w różne poziomy decydowania politycznego, a nie jedynie zaangażowanie wyborcze. Kompetencje polityczne, to zmienna zależna od liczby lat kształcenia formalnego [Domański 2005: 12]. Legitymizacja tego typu wiąże się również ze znacznym nasileniem kapitału pomostowego, czego skutkiem będzie poczucie sprawstwa. To z kolei, ma współegzystować z zaufaniem zgeneralizowanym, które w Polsce występuje na niewielkim poziomie [Czapiński, Panek 2011]. Należy również wziąć pod uwagę efekt skali. Na poziomie ogólnokrajowym „pełne” zaangażowanie, większej części obywateli wyrażone legitymizacją substancjonalną, przed pojawieniem się nowych mediów, trudno było sobie wyobrazić. Na poziomie polityki centralnej, nadal, najlepiej sprawdza się proceduralna postać działania systemu wyrażona przez demokrację przedstawicielską, co jest wymuszone znaczną liczebnością suwerena, a obecnie również coraz większym poziomem komplikacji rozstrzygnięć, co w pewnym zakresie zostało wypracowane przez rozrost administracji. Przez lata władze centralne państw demokracji liberalnych wypracowały wypaczony model sfery debaty publicznej. Podmiotem, a jednocześnie miejscem debaty stały się media tradycyjne, inne podmioty o zasadniczym znaczeniu w demokracji przedstawicielskiej, to politycy (partie polityczne) oraz obywatele, w dalszej kolejno- 
ści wymienić można grupy interesu (związki zawodowe, grupy komercyjnych aktorów w tym międzynarodowych, administracja). Największe znaczenie zyskali politycy i media dystansują znaczenie obywateli. Umocniło to znaczenie legitymizacji proceduralnej, a w konsekwencji niewydolności gospodarczej osłabieniu ulega również proceduralna funkcja systemu, przez malejące zaangażowanie suwerena $\mathrm{w}$ wyborach powszechnych. Wraz $\mathrm{z}$ tym procesem, następowało odejście polityki od ideologii, partie polityczne z masowych stawały się wyborczymi, a miejsce debaty publicznej stawało się teatrem, w którym gra się jedynie na emocjach. Coraz mniejsze znaczenie w tym kontekście ma komunikacja polityczna definiowana jako wypracowywanie konsensusu przez możliwie jak największą liczbę różnych aktorów zainteresowanych daną kwestią. Nieco inną perspektywę dla debaty publicznej stwarza pojawienie się tzw. nowych mediów, których głównym nośnikiem jest Internet w odsłonie Web 2.0 i wyższej. Internet w obecnej postaci „uzbraja” obywateli w możliwości skuteczniejszej kontroli swoich reprezentantów, komentowania i inicjowania decyzji politycznych, ubiegania się o swoje prawa, słowem, narzędzie to wzmacnia demokrację bezpośrednią i służy jej formom. Internet umożliwia obywatelom większy dostęp do zamkniętego dotąd kręgu komunikacji politycznej, również, a może przede wszystkim w odniesieniu do decydowania na poziomie centralnym. Stwarza to pewne nadzieje, na umocnienie „klasycznego pojmowania demokracji”, wzmocnienie partycypacji suwerena w kwestiach dotąd zarezerwowanych jedynie dla jego przedstawicieli, z decyzjami, których suweren się nie zgadza w trakcie trwania kadencji, czy wreszcie, na wzmocnienie siły legitymizacji demokratycznej w ogóle.

\section{Zakres zaangażowania}

W kontekście tego co powyżej scharakteryzowano, demokracja semibezpośrednia, z punktu widzenia wymogów definicyjnych sytuuje się gdzieś pomiędzy demokracją pośrednią a bezpośrednią. Gdyż, w rzeczywistości trudno jest zadośćuczynić kryteriom definicyjnym władztwa bezpośredniego. Stąd, demokracja semibezpośrednia w praktyce wpisywać się może również w niektóre założenia demokracji deliberacyjnej. Ta ostatnia, najogólniej, oznacza zaangażowanie w proces decyzyjny możliwie największej liczby obywateli, których dyskutowana problematyka dotyczy i którzy rozumieją własne stanowisko $\mathrm{w}$ tym zakresie i potrafią to stanowisko uzasadnić przy pomocy racjonalnych argumentów. Nadto, uczestnicy deliberacji to obywatele, a nie grupy nacisku; 
dostęp do procesu jest dla wszystkich zainteresowanych równy; uczestnicy mają rzetelne informacje o przedmiocie deliberacji co zakłada też wysiłek po stronie uczestników, który trzeba wydatkować na zdobycie wiedzy o problemie i wyrobienie własnego stanowiska. Dodatkowo, deliberacja ma polegać na poszukiwaniu zrozumienia dla własnych racji, a nie na budowie konsensusu, [Porębski 2012: 31]. Deliberacja w tym kontekście oznaczać będzie proces podejmowania decyzji, a nie samo decydowanie i finalne uzgadnianie rozstrzygnięcia. Zaangażowanie w proces, przedstawianie własnych opinii i wysłuchiwanie stanowiska innych wyłączając ostatnią fazę, czyli ustalanie decyzji wspólnej, gdzie strony przystają na zmiany w swoich pierwotnych stanowiskach.

Podsumowując, pojęcia: demokracja deliberacyjna, semibezpośrednia i bezpośrednia, mają tę wspólną cechę, że zakładają partycypację uczestników wspólnoty na różnym poziomie, w procesie sprawowania władzy, przedstawiania własnych stanowisk, uzgadniania decyzji i ich podejmowania. Choć, należy również zaznaczyć, że w polskim porządku prawnym udział obywateli na jakimkolwiek stopniu podejmowania decyzji jest utożsamiany z demokracją bezpośrednią. Odmienne rozumienie w konwencji prawnej, zaznacza się w przypadku państw Europy Zachodniej. Tam demokracja bezpośrednia będzie wówczas kiedy, to obywatele podejmują ostateczną decyzję. A w przypadku współudziału suwerena (jak ma to miejsce w konsultacjach) można jedynie mówić o demokracji semibezpośredniej [Uziębło 2005: 300]².

Generalnie, zaangażowanie członków wspólnoty w decydowanie polityczne wynika $z$ motywacji obywateli (partycypacja obywatelska/społeczna) oraz z motywacji władzy (partycypacja publiczna). To, jaka będzie rzeczywista skala zaangażowania obywateli jest w głównej mierze wypadkową tych dwóch czynników, na kształt których z kolei wpływają takie współzależne zmienne, jak: zaszłości historyczne, kultura narodowa, kultura polityczna na danym obszarze, postawy obywatelskie, kompetencje polityczne i wiele innych.

\section{Strukturalne uwarunkowania demokracji bezpośredniej w gminach}

W przypadku gmin jest możliwe aktywowanie mechanizmów demokracji bezpośredniej i deliberacji w szerszym zakresie. Dotyczy to szczególnie gmin niewielkich, właściwie, im mniejsza liczebność gminy, tym większe prawdo-

2 Niniejsza praca nie jest jednak prawniczym oglądem prezentowanej problematyki, a jedynie oglądem socjologicznym, stąd autor niniejszego artykułu definiuje konsultacje społeczne jako instytucję demokracji semibezpośredniej. 
podobieństwo efektywnego wdrożenia form demokracji bezpośredniej i semibezpośredniej. Składa się na to kilka czynników. Po pierwsze, wielkość zbiorowości, po drugie bliskość fizyczna i instytucjonalna lokalnych decydentów, po trzecie, „dojmujący” charakter lokalnych problemów dotyczących konkretnych reprezentantów zbiorowości. Czynniki te mogą spowodować, że zaangażowanie $\mathrm{w}$ proces decydowania w lokalnej polityce, będzie większe w małych, niż w dużych liczebnie zbiorowościach. W przypadku wielkości zbiorowości, większe zaangażowanie względnie małych liczbowo społeczności lokalnych dostrzegalne jest choćby w sytuacji wyborów samorządowych, co szczegółowo precyzuje teoria słabnięcia społeczności [Skarżyńska 2005: 207]. Zwykle frekwencja w tego rodzaju wyborach jest wyższa w małych gminach, niż w dużych ośrodkach miejskich. Poza tym, mała liczebność zbiorowości implikuje $\mathrm{z}$ „technicznego" punktu widzenia większą możliwość np. zabrania głosu w lokalnej debacie, oraz oferuje lepszą „słyszalność” pojedynczych stanowisk. Większe zaangażowanie suwerena w procesy decyzyjne na poziomie polityki lokalnej, umożliwia także sytuacja większej łatwości kontaktów z lokalnymi decydentami i mniejszej liczby barier administracyjnych stojących na drodze do takich kontaktów. Łatwiej spotkać lokalnego włodarza, niż np. ministra. Po trzecie, prawdopodobnie bardziej do działania zmotywuje propozycja likwidacji lokalnej szkoły, czy utrudniony dojazd do miejsca zamieszkania wskutek braku dobrej drogi, niż propozycja podniesienia podatków przez rząd centralny. Wszystkie te czynniki zwiększają możliwości szerokiego zaangażowania obywateli we współdecydowanie na poziomie lokalnym. Istotnym jest, na ile te strukturalne uwarunkowania sprzyjające „uśrednianiu” decyzji lokalna władza zechce wesprzeć i wykorzystać dla dobra wspólnego.

Ranga partycypacji publicznej i obywatelskiej wzrasta, do czego przyczyniają się niepowodzenia modeli wolnorynkowego i etatystycznego [Gąciarz, Bartkowski 2012: 75]. Konsultacje ${ }^{3}$, jako forma partycypacji obywatelskiej, wymagają od stron procesu spełnienia wielu warunków, jednak są bodaj najczęściej stosowanym narzędziem „uśredniania” decyzji politycznych, co w szczególności odnosi się do realizacji władzy na poziomie lokalnym.

3 Konsultacje społeczne można zdefiniować jako proces, w którym władza zasięga opinii społeczeństwa (organizacje społeczne, interesariusze w danej sprawie, obywatele, eksperci niezależni) w dowolnej kwestii. Ustalenia konsultacji powinny wpływać na kierunek legislacji. W obiegu jest też termin konsultacje publiczne, który ma oznaczać konsultacje szersze, niż konsultacje społeczne, bo konsultacje społeczne zakładać mają konsultowanie, głównie w ramach organizacji społecznych [Stanowisko 2013]. 


\section{Konsultacje społeczne po polsku}

Protesty przeciw ACTA na początku 2012 roku wywołały reakcję rządu w postaci organizacji tzw. Kongresów Wolności Internetu. Wydarzenia te przyczyniły się z kolei do powstania dokumentu Konsultacje społeczne - jak sprawić by były lepsze? Propozycja kodeksu konsultacji i ścieżka wdrożenia ${ }^{4}$. Treści tego dokumentu stały się tzw. Kodeksem Konsultacji Społecznych - wskazówką dla rządu i administracji, czym kierować się w przypadku przeprowadzania konsultacji. Dogmaty konsultacji społecznych wynikające $\mathrm{z}$ tego dokumentu, to: dobra wiara, powszechność, przejrzystość, responsywność, koordynacja, przewidywalność oraz poszanowanie interesu ogólnego; w sumie te przykazania tworzą tzw. Siedem Zasad Konsultacji. Po pewnym czasie z inicjatywy organizacji pozarządowych i Prezydenta RP, powstał również Kanon Konsultacji Lokalnych $^{5}$ [Makowski 2013]. Jest to rozwiązanie dedykowane gminom w fazie projektowania i przeprowadzania lokalnych konsultacji społecznych. We wcześniejszym okresie czasu powstało także szereg dokumentów instruktażowych oświetlających ideę konsultacji na poziomie samorządu i dedykowanych poszczególnym jednostkom samorządu terytorialnego JST, [Zychowicz 2011; Pyka 2011; Probosz, Sadura 2011].

Generalnie, motywacja do wdrażania konsultacji społecznych ze strony rządu w Polsce wynika z presji wewnętrznej i zewnętrznej. W przypadku tej pierwszej, idzie o sprawę ACTA ale i coraz częstsze wyrażanie, głównie negatywnych opinii przez obywateli na forum nowych mediów. Presja zewnętrzna wynika z wymogów stawianych przez organizacje takie jak Komisja Europejska czy OECD ${ }^{6}$. Prawdopodobnie, gdyby nie wystąpiła presja wewnętrzna, to niewiele by się w sprawie konsultacji zmieniło. Tymczasem obecnie (organizowane albo współorganizowane przez rządzących) konsultacje toczą się w wielu miejscach przestrzeni internetu i mają charakter testu. Do tej pory nie utworzono jednej platformy konsultacji on-line dla wszystkich aktów prawnych na szczeblu centralnym. Takie zalecenia formułuje dokument Kodeks Konsultacji Społecznych ${ }^{7}$. Sugestie w podobnym tonie widnieją także w dokumencie

\footnotetext{
https://mac.gov.pl/wp-content/uploads/2012/06/konsultacje-społeczne.pdf [10.10.2013].

http://issuu.com/res_publica_nowa/docs/cji_lokalnych_wst__pne_za__o__enia_?e=2095242/ 3910666\#search [10.10.2013].

6 Background Document on Public Consultation: http://www.oecd.org/mena/governance/36785341. pdf; w tym kontekście także [Koźlicka 2004:46].

7 Konsultacje społeczne - jak sprawić by były lepsze? Propozycja kodeksu konsultacji i ścieżka wdrożenia, s. 13.
} 
rządowym Program „Lepsze regulacje 2015 ” . Na mocy zapisów w tym ostatnim dokumencie, Ministerstwo Gospodarki (MG) testuje właśnie działanie platformy konsultacji on-line (konsultacje.gov.pl), ale tylko w ramach aktów prawnych $\mathrm{MG}^{9}$. Udział w konsultacjach w ramach tej platformy (aktywność na forum, przesyłanie opinii na temat aktów prawnych) dla osób fizycznych, wymaga rejestracji poprzez system ePUAP, co może być znacznym utrudnieniem, choć MG informuje, że proces ten przeszło już ponad 100 tys. osób ${ }^{10}$. W sumie, na 35 konsultowanych na platformie aktów prawnych, jedynie w przypadku Założenia ustawy - prawo o miarach, odnotowano ponad 2 tys. odsłon; w dalszej kolejności Krajowy Plan Rozwoju Kosmicznego odnotował ponad 1,5 tys. odsłon. Pozostałe projekty cieszą się mniejszym zainteresowaniem - poniżej 1 tys. odsłon ${ }^{11}$. Komentarze skupiają się wokół kilku projektów, a ich autorami są użytkownicy instytucjonalni, a nie osoby prywatne.

Ministerstwo Gospodarki prowadzi także platformę OSR ex post regulacji prawnych w domenie MG Zmieniaj $z$ nami prawo ${ }^{12}$. W tym przypadku istnieje jedynie możliwość komentowania sugerowanych aktów prawnych oraz wskazywania własnych propozycji aktów prawnych i wskazywania uciążliwości, jakie generują. W tym przypadku komunikacja jest jednostronna, nie można śledzić wpisów innych użytkowników, brak również jakiegokolwiek podsumowania zgłaszanych uwag.

Innym miejscem, gdzie mogą odbywać się konsultacje w sprawie rządowych projektów jest portal mamzdanie.org.pl ${ }^{13}$. To rozwiązanie dla użytkowników nieinstytucjonalnych jest bardziej przystępne niż platforma konsultacje.gov.pl, ponieważ, oprócz całego aktu prawnego poddanego konsultacji, oferuje również jego streszczenie i wskazanie celu konsultacji. W przypadku zakończenia procesu konsultacji występuje jego podsumowanie. Generalnie, to rozwiązanie odnotowuje większą liczbę interakcji tak po stronie osób fizycznych, jak i użytkowników instytucjonalnych niż inicjatywa MG. Na co wpływa też zapewne fakt, że na tej platformie konsultowane są propozycje z różnych resortów, ale istnieją tu również możliwości prowadzenia konsultacji np. przez samorządy.

Poza tym, funkcjonuje jeszcze platforma Rządowego Procesu Legislacyjnego $(\mathrm{RPL})^{14}$. Jednak jest to rozwiązanie skierowane głównie do legislatorów oraz

\footnotetext{
8 Program „Lepsze regulacje 2015”, s. 35.

9 http://konsultacje.gov.pl/

10 http://konsultacje.mg.gov.pl/node/3080 [01.11.2013].

11 Stan na 1.11.2013 http://konsultacje.mg.gov.pl/projects

12 http://bip.mg.gov.pl/Prawo/Zmieniaj+z+nami+prawo

13 https://mamzdanie.org.pl/web/guest

14 http://legislacja.rcl.gov.pl/
} 
podmiotów zrzeszonych (głównie z rozdzielnika) ${ }^{15}$. Dominującą funkcją jest tu funkcja informacyjna, a nie konsultacyjna. Chociaż, dla osób fizycznych w tym przypadku istnieje również możliwość zgłaszania własnych sugestii.

Oprócz sugerowanych powyżej działań inicjowanych przez rządzących istnieje wiele przykładów oddolnej aktywności obywatelskiej na łamach nowych mediów, głównie w portalach społecznościowych, które to działania noszą znamiona procesu konsultacji, albo precyzyjniej, żądania przez wyborców konsultacji w wybranych kwestiach.

Trzeba brać również pod uwagę fakt, że idea konsultacji w polskich warunkach, może napotykać bariery (głównie po stronie władzy) tak na poziomie centralnym, jak i lokalnym. Przyczyną tego może być tzw. polska kultura narodowa, którą charakteryzuje duży dystans władzy i znaczne unikanie niepewności [Boski 2009: 93; G. Hofstede, J.G. Hofstede 2007: 59].

\section{Konsultacje społeczne w świetle uchwał podlaskich samorządów}

Celem badania była analiza uchwał rad gminnych województwa podlaskiego dotyczących konsultacji społecznych. Dotyczyło to określenia przyjmowanych przez samorządy lokalne obwarowań zasad i trybu konsultacji oraz katalogu spraw, których konsultacje w charakteryzowanym okresie dotyczyły.

Analizie poddano uchwały podlaskich samorządów dotyczące konsultacji społecznych od 2009 roku do końca stycznia 2014 roku $^{16}$. Od początku 2009 roku rady gminne w województwie podlaskim przyjęły 89 uchwał dedykowanych konsultacjom w określonej sprawie oraz uchwał określających tryb i zasady prowadzenia wszystkich konsultacji w gminie. Ponadto, rady gminne, w obszarze województwa w charakteryzowanym okresie ogłosiły w sumie 23 nowelizacje wcześniej przyjętych uchwał dotyczących konsultacji dotyczących określonych kwestii i uchwał precyzujących przebieg wszystkich konsultacji w gminie. Dodatkowo, 10 uchwał dotyczy określenia zasad i trybu konsultacji (np. w postaci przyjęcia regulaminu konsultacji) z organizacjami pozarządowymi oraz innymi podmiotami prowadzącymi działalność w zakresie pożytku publicznego. Ponadto, w dwóch gminach przyjęto też uchwały wprowadzające Regulamin Konsultacji Społecznych.

15 http://bip.rcl.gov.pl/rcl/status-prawny/3536,dok.html

16 Źródło analizy stanowią wskazania Elektronicznego Dziennika Urzędowego Województwa Podlaskiego: http://edziennik.bialystok.uw.gov.pl [20.02.2014]. 
Konsultacje w gminach mogą mieć charakter obligatoryjny bądź fakultatywny ${ }^{17}$. Konsultacje fakultatywne mają być przeprowadzane $\mathrm{w}$ sprawach „ważnych dla gminy”, o czym decyduje rada gminy. Z kolei obligatoryjność konsultacji nie wynika jedynie z ustawy o samorządzie gminnym, może być podyktowana brzmieniem innych ustaw [Ustawa 2003]. Wreszcie, konsultacje mogą dotyczyć całej gminy albo jej wydzielonego obszaru, np. sołectwa czy dzielnicy z uwagi na istotę poruszanych zagadnień. Konsultacje również mogą odnosić się do wydzielonych grup społeczno-zawodowych, w zależności od przedmiotu konsultacji.

Ustawodawca pozostawił gminom możliwości samodzielnego określania zasad, form i trybu konsultacji. Toteż praktyka w tym zakresie jest różna, co dyktowane jest uwarunkowaniami lokalnymi. Jest to rozwiązanie uwzględniające różnice w kulturze politycznej czy liczebność poszczególnych JST. Określając tryb i zasady konsultacji gminy wybierają jeden $z$ trzech wariantów: a) określenie w jednej uchwale zasad i trybu konsultacji dla wszystkich konsultacji w gminie; b)określanie każdorazowo trybu i zasad konsultacji; c)przyjęcie ogólnych zasad i trybu dla wszystkich konsultacji w gminie, co sugeruje ich specyficzne doprecyzowywanie w przypadku poszczególnych konsultacji [Rachwał 2008: 332].

Z przeprowadzonej analizy wynika, że samorządy gminne w województwie podlaskim w charakteryzowanym okresie na 89 wszystkich wydanych uchwał dotyczących konsultacji społecznych wydały aż 49 uchwał, które zaliczyć można do powyższej kategorii „a” i „c". Czyli są to uchwały, w których określono zasady i tryb konsultacji dla wszystkich konsultacji prowadzonych w gminie oraz uchwały przyjmujące ogólne zasady i tryb konsultacji w gminie z możliwością ich dookreślenia w sytuacji konsultowania określonej sprawy (np. gmina Czyże czy miasto Zambrów [Uchwała nr 22.109.2012; Uchwała nr 161/XXXI/13]). Wśród tych 49 uchwał dominują te pierwsze. Uchwały z obydwu tych wariantów były wydawane głównie w roku 2012 - w sumie 24 uchwały tego typu.

W uchwałach precyzujących zasady i tryb konsultacji dla wszystkich konsultacji w gminie oraz w tych, w których przyjmowano ogólne zasady i tryb konsultacji dla wszystkich konsultacji w gminie dominującą formą konsultacji pozostaje zebranie mieszkańców. Spotykany rezerwuar pozostałych form, to np. ankiety dystrybuowane w różnoraki sposób (w tym przez stronę urzędu gminy

17 Konsultacje obligatoryjne przewiduje się w następujących sprawach: a)tworzenia, łączenia, podziału i znoszenia gmin oraz ustalania ich granic; b)nadania gminie lub miejscowości statusu miasta i ustalenia jego granic; c)ustalenia lub zmiany nazw gmin oraz siedzib ich władz; d)utworzenia jednostki pomocniczej z inicjatywy rady gminy; e)ustalenia statutu jednostki pomocniczej [za: Rachwał 2008:330]. 
i BIP, na zebraniach z mieszkańcami), karty konsultacyjne, pisemne zapytania mieszkańców, udostępnianie dokumentów dotyczących konsultowanych treści, przyjmowanie opinii i wniosków (w formie pisemnej, przez komunikację elektroniczną). Z tego, zebrania $\mathrm{z}$ mieszkańcami wskazano w sumie w 41 spośród 49 uchwał. Wśród tych uchwał są takie, gdzie nie doprecyzowano form i zasad konsultacji, jak np. w uchwale Rady Miejskiej w Czyżewie [Uchwała w XVII/115/12], gdzie wskazano jedynie, że stosowana będzie karta konsultacyjna z pytaniami dotyczącymi konsultowanej sprawy. Nie określono tam sposobów dystrybucji i zbierania owej karty konsultacyjnej. Z treści uchwały wynika również, że niekoniecznie wypracowywanie treści pytań/opcji wyboru do karty konsultacyjnej musi się odbywać podczas np. zebrań z mieszkańcami. Podobna w brzmieniu jest uchwała Rady Gminy Raczki [Uchwała nr XV/80/12]. Tam również wspomina się jedynie o karcie konsultacyjnej jako formie konsultacji. Przyjęciem ogólnych zasad i trybu dla wszystkich konsultacji bez podania w treści uchwały jakiejkolwiek formy konsultacji, charakteryzuje się z kolei uchwała gminy Radziłów [Uchwała nr XVII/111/11]. Z kolei, w gminie Goniądz uchwała przewiduje sposób prowadzenia konsultacji jako konsultacje „ustną” i „pisemną”, gdzie również pozostawiono swobodę w dalszym możliwym doprecyzowywaniu przebiegu konsultacji [Uchwała nr XIV/83/11].

$\mathrm{Z}$ drugiej strony, w charakteryzowanym okresie powstały uchwały określające przebieg wszystkich konsultacji w gminie, w których dookreślono szeroki zakres stosowanych form konsultacji. Przykładem takiej uchwały jest uchwała Rady Gminy Nowinka [Uchwała nr X/71/11]. Przewidywane przez tę uchwałę formy prowadzenia konsultacji, to m.in.: badania ankietowe, sondaże internetowe, spotkania radnych i wójta $\mathrm{z}$ mieszkańcami. W uchwale nie dookreślono szczegółowych sposobów wdrażania tych form konsultacji. Z kolei, dookreślony katalog form konsultacji, których wdrożenie zostało szczegółowo scharakteryzowane, wprowadza się w uchwale gminy Białowieża [Uchwała nr XXVIII/151/09]. Formy te, to: zebrania mieszkańców, spotkania konsultacyjne $\mathrm{z}$ przedstawicielami organizacji działających na terenie gminy oraz badania opinii z wykorzystaniem formularza ankietowego.

W omawianym okresie czasu, należy tez wymienić, powstanie dwóch uchwał wprowadzających tzw. Regulamin Konsultacji Społecznych. Uchwały te precyzują przebieg konsultacji fakultatywnych $w$ sprawach ważnych dla mieszkańców (miasta/gminy przyp. autor). Przykładem tego rodzaju jest uchwała Rady Miasta w Hajnówce [Uchwała nr VI/31/11]. W uchwale tej określono szeroki zakres form konsultacji, jedną nich są np. warsztaty projektowe umożliwiające zainteresowanym zdobycie wiedzy na temat konsultowanego tematu $i$ wypracowanie rozwiąań zakończonych sporządzeniem pisemnego podsumowania zawieraja- 
cego wszystkie opinie i wnioski. Bardzo precyzyjnie opisano zasady prowadzenia konsultacji, szczegółowo scharakteryzowano proces informowania o konsultacjach, gdzie nacisk położono na informowanie o sprawie, której konsultacje dotyczą. Regulamin konsultacji zakłada również, co nie jest nigdzie spotykane, udział ekspertów $\mathrm{z}$ danej dziedziny w sytuacji prowadzenia konsultacji wymagających specjalistycznej wiedzy. Dodatkowo, przewidywane jest prowadzenie zakładki na stronie internetowej urzędu miasta, dedykowanej konsultacjom, która zawierać ma m.in. forum dyskusyjne, informacje o przedmiocie konsultacji oraz dokumentację związaną z konsultacjami. Drugą uchwałą, która wprowadza Regulamin Konsultacji Społecznych dla konsultacji fakultatywnych w gminie, jest uchwała Rady Gminy Hajnówka [Uchwała nr XIII/64/11], zbliżona treściowo do powyższej uchwały Rady Miasta Hajnówka.

Uchwały ściśle i ogólnie precyzujące przebieg wszystkich konsultacji w gminie charakteryzuje też zbliżone podejście inicjowania konsultacji przez mieszkańców. Gminy określają tu albo dolny próg odsetka mieszkańców gminy, albo obszaru, którego konsultacje dotyczą, posiadających czynne prawo wyborcze do rady gminy, albo wymaganą liczbę mieszkańców inicjujących proces. $\mathrm{Z}$ reguły wymaga się, aby inicjatywę wszczęcia konsultacji poparło $10 \%$ lub 20\% mieszkańców gminy albo jednostki, której konsultacje mają dotyczyć. Ewentualnie, w uchwałach podaje się wymaganą liczbę mieszkańców popierających zainicjowanie procesu konsultacji i liczbę tę najczęściej gminy określają na poziomie 100 bądź 50 osób. Choć, np. uchwała gminy Jaświły umożliwia złożenie wniosku przez mieszkańców o przeprowadzenie konsultacji, pod którym to wnioskiem podpisy złoży co najmniej 10 mieszkańców gminy z czynnym prawem wyborczym do rady gminy [Uchwała nr XXXIV/167/10]. Z kolei, w gminie Radziłów wymagany jest wniosek o wszczęcie konsultacji podpisany przez 25 osób uprawnionych do udziału w konsultacjach [Uchwała nr XVII/111/11]. Częściej jednak w uchwałach wskazywano na procent ogółu mieszkańców gminy albo jednostki/obszaru niż na konkretną ich liczbę, jeżeli idzie o możliwość inicjowania konsultacji. Jednak, aż w 22 uchwałach na 49 tego typu, nie określono kryteriów inicjowania konsultacji przez mieszkańców.

W tego typu uchwałach niekiedy określa się też próg ważności konsultacji, co wymaga np. zebrań z mieszkańcami i ewidencjonowania biorących udział. Według uchwały gminy Brańsk za ważne uważa się konsultacje, jeżeli wzięło w nich udział co najmniej 30\% uprawnionych mieszkańców gminy, ale tylko w sytuacji, kiedy przedmiot konsultacji dotyczy całej gminy [Uchwała nr XVII/145/13]. Z kolei, np. w gminie Klukowo wymagany dla ważności konsultacji próg uczestnictwa to 10\% uprawnionych [Uchwała nr XXIII/140/14]. Jeżeli już określano wymagany próg uczestnictwa w konsultacjach dla ich waż- 
ności, to proporcje te oscylowały w od $10 \%$ do $30 \%$. Zwykle unikano precyzowania tego wymogu, co jest zasadne w sytuacji stosowania różnych form konsultacji i wykorzystywania w tym celu różnorodnych kanałów komunikacji.

W uchwałach z charakteryzowanego okresu, które dotyczyły konsultacji obligatoryjnych stosowano na ogół samą kartę konsultacyjną (niekiedy nazywaną ankietą konsultacyjną), która była w różny sposób udostępniana uprawnionym do wypełnienia, np. podczas zebrań z mieszkańcami.

Analizując pozostałe kwestie i elementy szczegółowe, wynikające z zapisów w uchwałach rad gminnych dedykowanych konsultacjom w charakteryzowanym okresie, wymienić można uchwałę Rady Gminy Czyże [Uchwała nr 22.109.2012], w której przewidziano udział w konsultacjach osób, które ukończyły 13 lat, decyduje o tym rada gminy. Rozwiązanie tego typu nie występuje w żadnej innej uchwale w ramach analizowanych. W zapisach niektórych uchwał istnieją też rozbieżności w zakresie jawnego albo tajnego wyrażania poparcia dla określonych opcji na karcie konsultacyjnej albo ankiecie stosowanej w trakcie konsultacji. Na przykład w uchwale gminy Krypno [Uchwała $\mathrm{nr} \mathrm{X} / 52 / 2011]$ za ważne uznaje się ankiety konsultacyjne opatrzone podpisem. Z kolei uchwała gminy Bielsk Podlaski [Uchwała nr XXIX/153/09] w sprawie konsultacji dotyczących zmiany nazwy wsi dopuszcza możliwość głosowania tajnego w sytuacji, jeżeli uczestniczący konsultacji w czasie zebrania podejmą taką decyzję większością głosów.

Generalnie, we wszystkich uchwałach tego typu, zasady konsultacji charakteryzowano dość wybiórczo, akcentując przeważnie proceduralną rolę poszczególnych czynności. Dotyczy to szczególnie konsultacji w sprawach zmian nazw miejscowości.

\section{Katalog spraw poddawanych konsultacjom}

Od 2009 do marca 2014 roku gminy w województwie podlaskim poddawały konsultacjom następujące sprawy, na które, ze względu na liczbowy albo unikalny charakter należy zwrócić uwagę:

1. Zmiany granic gminy - w gminie Choroszcz [Uchwała nr XVII/174/2013] oraz w gminie Supraśl [Uchwała nr VI/57/11]. W obydwu przypadkach konsultacje odbywały się w formie głosowania $\mathrm{z}$ użyciem karty konsultacyjnej. W Supraślu głosowanie odbywało się podczas zebrania mieszkańców, gdzie uczestnicy mieli być wyczerpująco informowani o przedmiocie konsultacji. W Choroszczy natomiast należało samodzielnie 
uzyskać kartę konsultacji, a po uzupełnieniu złożyć w odpowiednich miejscach wyznaczonych na terenie gminy.

2. Łączenie, podział i likwidacja sołectw - w gminie Klukowo mieszkańcom zadano pytanie: „Jakie jest Pana/Pani stanowisko w sprawie połączenia sołectw Klukowo i Klukowo-Kolonia w jedno wspólne sołectwo pod nazwą "sołectwo Klukowo", obejmujące w całości obszar dotychczasowych sołectw Klukowo i Klukowo-Kolonia?". W konsultacjach stosowano kartę konsultacyjną, gdzie pozostawiono dwie opcje wyboru: „popieram połączenie sołectw” oraz „jestem przeciwko połączeniu sołectw”. Formą konsultacji pozostaje tu zebranie mieszkańców, choć $\mathrm{w}$ treści uchwały nie wspomniano o tym bezpośrednio [Uchwała $\mathrm{nr}$ XIV/86/12]. W gminie Juchnowiec Kościelny w 2012 roku konsultowano podział sołectwa Simuny i utworzenie na jego bazie dwóch jednostek pomocniczych [Uchwała nr XIV/130/2012]. Z kolei w gminie Krynki w 2011 roku konsultacjom poddano likwidację dwóch sołectw i przyłączenia wsi do innych sołectw [Uchwała nr VI/39/2011]. W gminie Sokółka w 2011 przyjęto dwie uchwały dotyczące konsultowania odłączenia wsi od sołectwa i utworzenia odrębnego sołectwa, na wniosek mieszkańców tych wsi [Uchwała nr VIII/43/11].

3. Zmiana nazwy miejscowości - uchwały o tej tematyce dominowały przede wszystkim w 2009 roku. Ogółem w charakteryzowanym okresie przyjęto 14 uchwał w tej sprawie, $\mathrm{z}$ czego 12 podjęto w 2009 roku, a po jednej uchwale w 2010 i 2011 roku. Konsultacje tego typu wdrażano w oparciu o zapisy ustawy z dnia 29 sierpnia 2003 roku o urzędowych nazwach miejscowości i obiektów fizjograficznych. Konsultacje tego typu przeprowadzano $\mathrm{w}$ formie zebrań $\mathrm{z}$ mieszkańcami i stosowaniu karty konsultacyjnej. Ewentualnie, pomijano fazę zebrań z mieszkańcami, a rozprowadzano jedynie przyjęty w uchwale wzór karty konsultacyjnej, np. przez sołtysów.

4. Statuty jednostek pomocniczych gminy - w charakteryzowanym okresie powstały 3 uchwały w 3 gminach odnoszące się opiniowania statutów jednostek pomocniczych oraz jedna uchwała przewidująca konsultacje w sprawie zaopiniowania zmian w statutach jednostek pomocniczych [Uchwała nr XXVIII/220/09].

5. Budżet obywatelski - dwie uchwały: rady miejskiej w Suwałkach [Uchwała nr XLIV/483/2013] i Białymstoku [Uchwała nr XLVIII/534/13]. Te przykłady konsultacji dotyczących budżetu obywatelskiego wyróżniają rozbudowane formy, w których mieszkańcy zgłaszają najpierw propozycje inwestycji infrastrukturalnych, które po zaakceptowaniu 
przez władze lokalne pod względem przyjętych kryteriów formalnych, podlegają ponownemu głosowaniu przez mieszkańców. Finansowanie dotyczy inwestycji, które zbiorą największe poparcie społeczne przy założeniu dostępnej puli środków.

6. Duże inwestycje infrastrukturalne - pojawiła się jedna taka uchwała dotycząca lokalizacji lotniska regionalnego w Topolanach $\mathrm{w}$ gminie Michałowo [Uchwała nr XXVIII/257/09].

7. Problematyka uzależnień - w gminie Choroszcz w 2011 roku przyjęto uchwałę zakładającą konsultacje społeczne projektu Programu Profilaktyki i Rozwiązywania Problemów Uzależnień na rok 2012 na terenie Gminy Choroszcz [Uchwała nr V/63/2011]. Tryb i zasady konsultacji zakładały zgłaszanie pisemnych uwag, zastrzeżeń i wniosków do projektu Programu.

\section{Podsumowanie}

W świetle przeprowadzonej analizy wynika, że większość uchwał gmin w województwie podlaskim od 2009 do końca stycznia 2014 roku dotyczyło określenia w jednej uchwale mniej lub bardziej doprecyzowanych zasad i trybu prowadzenia konsultacji dla wszystkich konsultacji w gminie. Pozostałe odnoszą się do konsultacji, głównie obligatoryjnych. Konsultuje się dość oszczędnie i „standardowo”. Ogólnie, można odnieść wrażenie, że konsultacje przez samorządy traktowane są bardziej proceduralnie, niż substancjalnie a wachlarz potencjalnych metod konsultacji jest niewielki. Dominującą formą konsultacji, pozostają zebrania z mieszkańcami oraz tzw. karta konsultacyjna. Zebrania z mieszkańcami częstokroć i tak nie wykluczają finalnego zastosowania karty konsultacyjnej. Stosowanie tej ostatniej formy, bez wcześniejszych zebrań z mieszkańcami, albo gdy zebrania z mieszkańcami nie wpływają ostatecznie na kształt karty konsultacyjnej mija się z duchem instytucji konsultacji, gdyż zawęża opinie do wyboru alternatywnych opcji. Taka praktyka może mieć zastosowanie w przypadku konsultacji, w sprawach zmiany nazwy miejscowości, $\mathrm{w}$ pozostałych przypadkach należałoby dopuszczać w pierwszej fazie procesu zgłaszanie zastrzeżeń, opinii, wniosków suwerena i szeroką dyskusję, a w dalszej kolejności na tej podstawie wypracować kafeterię wyboru w karcie konsultacyjnej. Być może karata konsultacyjna występująca $\mathrm{w}$ fazie zakończenia konsultacji nie powinna ograniczać się do wyboru opcji alternatywnych, ale powinna zawierać szersze spektrum wyboru. 
Rzadko spotykanym rozwiązaniem jest dopuszczenie możliwości przeprowadzenia badania sondażowego w odniesieniu do konsultowanych kwestii, które to badanie miałoby być zlecane wyspecjalizowanym podmiotom zewnętrznym. Takie rozwiązanie może się również wiązać z redukcją opinii mieszkańców, co oczywiście zależne jest od konstrukcji narzędzia badawczego. Jednak można przyjąć, że tak właśnie będzie się działo, co wynika z faktu, że gminy dążąc do ograniczenia kosztów konsultacji wybierać będą warianty najtańszych oferentów, którzy w takich okolicznościach wybiorą najprawdopodobniej scenariusz badania CATI. Zatem, mimo ewentualnej reprezentatywności badania, stracić może idea konsultacji, w której należy dążyć do bezpośredniej wymiany poglądów.

Częstokroć uchwały precyzujące tryb i zasady konsultacji w gminie dopuszczają łączenie różnych przewidzianych form konsultacji w zależności od przedmiotu konsultacji i obszaru na którym się one odbywają. Dopuszczane formy konsultacji w JST w województwie podlaskim, oprócz wymienionych, to także: pisemne i/lub elektroniczne zapytania wysyłane do mieszkańców, nadto prośby o wyrażenie opinii, sugestii w formie pisemnej i/lub elektronicznej. W stosowanych formach konsultacji komunikację elektroniczną stosuje się ostrożnie i najczęściej ogranicza do zamieszczania informacji i materiałów dotyczących konsultowanej sprawy w BIP, czy na stronie internetowej gminy, ewentualnie do komunikacji mailowej lub korzystania z elektronicznych formularzy urzędów. Nie wykorzystuje się takich kanałów komunikacji, jak blogi, czaty, fora dyskusyjne.

\section{Bibliografia}

Boski P. (2009), Kulturowe ramy zachowań społecznych, Warszawa

Czapiński J., Panek T. (red.), (2011), Diagnoza społeczna

Cześnik M. (2007), Partycypacja wyborcza w Polsce. Perspektywa porównawcza, Warszawa

Domański H. (2005), Legitymizacja systemu politycznego w dwudziestu jeden krajach, „Studia Socjologiczne" nr 2

Gąciarz B., Bartkowski J. (2012), Samorząd a rozwój, Warszawa

Hofstede G., Hofstede J. G. (2007), Kultury i organizacje, Warszawa

Kossowska-Gąstoł B. (2004), Demokracja bezpośrednia w III RP - fikcja czy rzeczywistość, [w:] W. Kaut (red.), Demokracja, liberalizm, społeczeństwo obywatelskie, Katowice

Koźlicka R. (2004), Unia Europejska wobec organizacji pozarządowych: konsekwencje dla trzeciego sektora $w$ Polsce, [w:] P. Gliński, B. Lewenstein, A. Siciński (red.), Samoorganizacja społeczeństwa polskiego: III sektor $i$ wspólnoty loklane $w$ jednoczącej się Eurpie, Warszawa 
Uziębło P. (2005), Konstrukcja prawna i funkcjonowanie instytucji demokracji bezpośredniej i semibezpośredniej w państwach Europy Centralnej, „Gdańskie Studia Prawnicze” t. XIV Uziębło P. (2009), Demokracja partycypacyjna, Gdańsk.

Porębski L. (2012), Debata lokalna jako środek realizacji idei demokracji bezpośredniej, [w:] Demokracja bezpośrednia $w$ samorządzie terytorialnym, Lublin

Probosz M., Sadura P. (2011), Konsultacje w społeczności lokalnej: planowanie, przygotowanie, prowadzenie konsultacji społecznych metoda warsztatowa, Warszawa

Pyka M. (2011), Poradnik „Dobrych Praktyk Konsultacji Społecznych”, Warszawa

Rachwał M. (2008), Konsultacje z mieszkańcami gminy jako instytucja demokracji bezpośredniej, [w:] S. Michałowski, K Kuć-Czajkowska (red.), Przywództwo lokalne a kształtowanie demokracji partycypacyjnej, Lublin

Skarżyńska K. (2005), Człowiek a polityka. Zarys psychologii politycznej, Warszawa

Wesołowski W. (2001), Legitymizacja jako potoczna filozofia władzy, „Studia Socjologiczne” nr 2

Zychowicz Z. (red.), (2011), Przeprowadzanie konsultacji społecznych w samorzadzie, Szczecin

\section{Dokumenty sejmowe i samorządu terytorialnego}

Uchwała nr 161/XXXI/13 Rady Miasta Zambrów z 10 września 2013 r. w sprawie zasad i trybu przeprowadzania konsultacji społecznych z mieszkańcami Gminy Miasta Zambrów

Uchwała nr 22.109.2012 Rady Gminy Czyże z dnia 28 grudnia 2012 r. w sprawie zasad i trybu przeprowadzania konsultacji z mieszkańcami gminy Czyże

Uchwała nr V/63/2011 Rady Miejskiej w Choroszczy z dnia 2 września 2011 r. w sprawie przeprowadzenia konsultacji społecznych projektu Programu Profilaktyki i Rozwiązywania Problemów Uzależnień na rok 2012 na terenie Gminy Choroszcz

Uchwała nr VI/31/11 Rady Miasta Hajnówka z dnia 30 marca 2011 r. w sprawie wprowadzenia Regulaminu Konsultacji Społecznych

Uchwała nr VI/39/2011 Rady Miejskiej w Krynkach z dnia 16 czerwca 2011 r. w sprawie przeprowadzenia konsultacji z mieszkańcami Sołectwa Rudaki i Nietupa

Uchwała nr VI/57/11 Rady Miejskiej w Supraślu z dnia 24 marca 2011 r. w sprawie zasad i trybu przeprowadzenia konsultacji społecznych z mieszkańcami w przedmiocie zmiany granic Gminy Supraśl

Uchwała nr VIII/43/11 Rady Miejskiej w Sokółce z dnia 4 lutego 2011 r. w sprawie przeprowadzenia konsultacji z mieszkańcami Sołectwa Szyndziel-Gilbowszczyzna

Uchwała nr VIII/44/11 Rady Miejskiej w Sokółce z dnia 4 lutego 2011 r. w sprawie przeprowadzenia konsultacji z mieszkańcami Sołectwa Geniusze

Uchwała nr X/52/2011 Rady Gminy Krypno z dnia 23 września 2011 r. w sprawie określenia zasad i trybu przeprowadzania konsultacji społecznych z mieszkańcami Gminy Krypno

Uchwała nr X/71/11 Rady Gminy Nowinka z dnia 30 grudnia 2011 r. w sprawie zasad i trybu przeprowadzania konsultacji z mieszkańcami Gminy Nowinka

Uchwała nr XIII/64/11 Rady Gminy Hajnówka z dnia 29 grudnia 2011 r. w sprawie wprowadzenia Regulaminu Konsultacji Społecznych 
Uchwała nr XIV/130/2012 Rady Gminy Juchnowiec Kościelny z dnia 16 marca 2012 r. w sprawie przeprowadzenia konsultacji z mieszkańcami

Uchwała nr XIV/83/11 Rady Miejskiej w Goniądzu z dnia 21 grudnia 2011 r. w sprawie określenia zasad i trybu przeprowadzania konsultacji z mieszkańcami gminy Goniądz

Uchwała nr XIV/86/12 Rady Gminy Klukowo z dnia 19 października 2012 r. w sprawie ustalenia zasad i trybu przeprowadzenia konsultacji z mieszkańcami sołectw Klukowo i Klukowo-Kolonia

Uchwała nr XLIV/483/2013 Rady Miejskiej w Suwałkach z dnia 30 grudnia 2013 r. w sprawie przeprowadzenia na terenie Miasta Suwałk konsultacji społecznych w sprawie Budżetu Obywatelskiego jako części budżetu miasta na 2014 rok

Uchwała nr XLVIII/534/13 Rady Miasta Białystok z dnia 25 czerwca 2013 r. w sprawie przeprowadzenia na terenie miasta Białystok konsultacji społecznych w sprawie Budżetu Obywatelskiego jako części budżetu Miasta Białegostoku na 2014 rok.

Uchwała nr XV/80/12 Rady Gminy Raczki z dnia 28 marca 2012 r. w sprawie określenia zasad i trybu przeprowadzania konsultacji z mieszkańcami Gminy Raczki

Uchwała nr XVII/111/11 Rady Gminy Radziłów z dnia 30 grudnia 2011 r. w sprawie zasad i trybu przeprowadzania konsultacji z mieszkańcami gminy

Uchwała nr XVII/115/12 Rady Miejskiej w Czyżewie z dnia 22 marca 2012 r. w sprawie określenia zasad i trybu przeprowadzania konsultacji z mieszkańcami Gminy Czyżew

Uchwała nr XVII/145/13 Rady Gminy Brańsk z dnia 21 lutego 2013 r. w sprawie określenia zasad i trybu przeprowadzania konsultacji społecznych z mieszkańcami Gminy Brańsk

Uchwała nr XVII/174/2013 Rady Miejskiej w Choroszczy z dnia 17 maja 2013 r. w sprawie zasad i trybu przeprowadzenia konsultacji z mieszkańcami gminy Choroszcz w przedmiocie zmiany granic gminy Choroszcz

Uchwała nr XXIII/140/14 Rady Gminy Klukowo z dnia 23 stycznia 2014 r. w sprawie określenia zasad i trybu przeprowadzania konsultacji społecznych z mieszkańcami gminy Klukowo

Uchwała nr XXIX/153/09 Rady Gminy Bielsk Podlaski z dnia 25 maja 2009 r. w sprawie przeprowadzenia konsultacji społecznych z mieszkańcami wsi Hryniewicze Duże i Orzechowicze dotyczących zmiany nazwy wsi

Uchwała nr XXVIII/ 257 /09 Rady Miejskiej w Michałowie z dnia 23 kwietnia 2009 r. w sprawie przeprowadzenia konsultacji z mieszkańcami Gminy Michałowo w sprawie lokalizacji lotniska regionalnego $\mathrm{w}$ Topolanach

Uchwała nr XXVIII/151/09 Rady Gminy Białowieża z dnia 31 lipca 2009 r. w sprawie określenia zasad i trybu przeprowadzania konsultacji społecznych z mieszkańcami Gminy Białowieża

Uchwała nr XXVIII/220/09 Rady Miejskiej w Lipsku z dnia 28 września 2009 r. w sprawie przeprowadzenia konsultacji dotyczących zaopiniowania przez mieszkańców zmian do statutów jednostek pomocniczych

Uchwała nr XXXIV/167/10 Rady Gminy Jaświły z dnia 29 czerwca 2010 r. o określeniu zasad i trybu przeprowadzania konsultacji społecznych

Ustawa z dnia 29 sierpnia 2003 r. o urzędowych nazwach miejscowości i obiektów fizjograficznych (Dz.U. nr 166 poz.1612) 


\section{Źródła elektroniczne}

http://www.szczecin.pl/UMSzczecinSwiat/files/AD4F41AB6CB94E78993C199743E0FB84/ Podręcznik\%20przeprowadzania\%20konsultacji\%20społecznych\%20w\%20samorządzie. pdf [10.10.2013].

Makowski G., Kanon Konsultacji Lokalnych. Wstępne założenia zaprezentowane 17 kwietnia 2013 roku, http://issuu.com/res_publica_nowa/docs/cji_lokalnych_wst_pne_za_o__ enia_?e=2095242/3910666\#search [10.10.2013]

Stanowisko Obywatelskiego Forum Legislacji przy Fundacji im. S. Batorego w sprawie zasad i trybu przeprowadzania konsultacji publicznych projektów ustaw oraz ich założeń (tezy), s. 1; http://www.batory.org.pl/doc/StanowiskoOFL_20111012.pdf [10.10.2013] 


\section{SUMMARY}

Public Consultations as an Aspect of Semi-Direct Democracy in the Local Governance of Podlaskie Voivodeship

The article presents the review of resolutions adopted by Podlaskie Voivodeship municipal councils dedicated to public consultations in a five-year perspective. This thread is preceded by the presentation of the idea of consultations as well as direct and semi-direct democracy from the State and self-government powers' point of view. Moreover, structural conditioning of the participation of subjects at the local self-government level has been characterized.

Keywords:

public consultations, participation, municipalities, Podlaskie Voivodeship 